UDC 574.472.42

\title{
FEATURES OF GRASS AND SUBSHRUB REPRODUCTION IN FOREST PHYTOCOENOSES
}

\section{M. Kovalenko}

Sumy National Agrarian University, 160, Gerasym Kondratjev St., Sumy 40021, Ukraine e-mail: kovalenko_977@mail.ru

The north-east region of Ukraine stands out from the other regions including the Carpathians for high forest cover. Grass and subshrub layer significantly affects the formation of tree layer (the early stages of forest demutation). The study is conducted in forest phytocoenoses of the National Nature Park "Desniansko-Starogutsky" and the adjacent territories. The study objects are model plant species of grass and subshrub layer (Aegopodium podagraria L., Asarum europaeum L., Calluna vulgaris (L.) Hull, Carex pilosa Scop., Molinia caerulea (L.) Moench., Stellaria holostea L., Vaccinium myrtillus L., Vaccinium vitis-idaea L.), each presented by 3-5 coenopopulations. Two main types of reproduction are found in forest grasses and subshrubs: seed (or by spores in spore-bearing plants) and vegetative. In case of generative reproduction, an important biological characteristic is the so-called reproductive effort, which characterizes the contribution of organic matters and energy to the reproductive process. An important common feature of reproduction of the vast majority of forest grasses is the ability for vegetative reproduction and clone formation. It is established that the main indicators of generative reproduction of clone forming plants of grass and subshrub layer depend on plant species, and are influenced by the ecological and coenotic factors. It has been found that the smallest contribution $(2 \%)$ to the reproduction organs is characteristic of C. vulgaris, and the highest contribution (almost $50 \%$ ) is found in the coenopopulations of $M$. caerulea. Overall, generativity of the studied plants of grass and subshrub layer is determined by the ecological and coenotic factors, and, therefore, is consistently varied from association to association.

Keywords: reproduction, forest ecosystems, grasses and subshrubs, reproductive effort.

\section{INTRODUCTION}

The north-east region of Ukraine stands out from the other regions including the Carpathians for high forest cover. Many works are primarily focused on the description of vegetation of this region, forest phytocoenoses in particular $[2,8,12,13,16,19,20$, $23,29]$. According to geobotanical zoning, the area where the study has been conducted belongs to the European broad-leaved forests, Eastern-European province, and covers two subprovinces - the Eastern European, and the Polisky and Podilsky and

ISSN 1996-4536 (print) • ISSN 2311-0783 (on-line) • Біологічні Студії / Studia Biologica • 2016 • Том 10/№1 • C. 187-196 
Middle Dnieper. S. M. Panchenko [23] developed syntaxonomic prodomus of vegetation of the National Nature Park "Desniansko-Starogutsky".

According to our descriptions, syntaxons of Vaccinio-Piceetea class are the most common ones in the forest ecosystems of Novgorod-Siversky Polissya. 2 orders, 4 unions and 11 associations can be allocated in this class as a whole [14].

Grass and subshrub layer significantly affects the formation of tree layer (the early stages of forest demutation). Depending on the composition and abundance of plants of grass and subshrub layer, the number of seedlings and little undergrowth of all woody species of trees is reduced in varying degrees, and the indicators of their growth are getting worse. Therefore, the study of characteristics of the production process of grass and subshrub populations is a current scientific problem.

\section{MATERIALS AND METHODS}

The study was conducted in forest phytocoenoses of the National Nature Park "Desniansko-Starogutsky" and the adjacent territories. The objects of the study were model plant species of grass and subshrub layer (Aegopodium podagraria L., Asarum europaeum L., Calluna vulgaris (L.) Hull, Carex pilosa Scop., Molinia caerulea (L.) Moench., Stellaria holostea L., Vaccinium myrtillus L., Vaccinium vitis-idaea L.), presented by $3-5$ coenopopulations.

The morphometric parameters of the generative sphere such as weight of generative organs (g), number of generative shoots (pieces), reproductive effort (\%), proportion of generative individuals in the population (\%) were defined in the populations of the studied species (Table 1).

Table 1. Brief geobotanical characteristics of forest associations with participation of herbaceous and subshrub layer dominants

Таблиця 1. Коротка геоботанічна характеристика лісових асоціацій з використанням домінантів трав'яно-чагарничкового ярусу

\begin{tabular}{|c|c|c|c|c|c|}
\hline $\begin{array}{l}\text { Number and name } \\
\text { of association }\end{array}$ & $\begin{array}{l}\text { Composition } \\
\text { of tree stand }\end{array}$ & $\begin{array}{l}\text { Stand } \\
\text { density }\end{array}$ & $\begin{array}{c}\text { Average } \\
\text { stand age, } \\
\text { year }\end{array}$ & $\begin{array}{l}\text { Average } \\
\text { stand } \\
\text { height, } m\end{array}$ & $\begin{array}{c}\text { Average } \\
\text { projective } \\
\text { cover of } \\
\text { dominant, \% }\end{array}$ \\
\hline \multicolumn{6}{|c|}{ Aegopodium podagraria } \\
\hline I. Quercetum coryloso-aegopodiosum & 6Q4P & 0.7 & 79 & 27 & 55 \\
\hline $\begin{array}{l}\text { II. Querceto-Pinetum coryloso- } \\
\text { aegopodiosum }\end{array}$ & $7 \mathrm{P} 3 \mathrm{Q}$ & 0.6 & 61 & 27 & 60 \\
\hline $\begin{array}{l}\text { III. Betuleto-Pinetum coryloso- } \\
\text { aegopodiosum }\end{array}$ & $6 P 4 B+Q$ & 0.8 & 53 & 24 & 55 \\
\hline \multicolumn{6}{|c|}{ Asarum europaeum } \\
\hline I. Quercetum coryloso-asarosum & $8 Q 2 P+B$ & 0.7 & 65 & 23 & 60 \\
\hline II. Pinetum coryloso-asarosum & $9 P 1 Q+B$ & 0.8 & 68 & 24 & 50 \\
\hline III. Querceto-Pinetum asarosum & $6 \mathrm{P} 4 \mathrm{Q}$ & 0.5 & 59 & 22 & 65 \\
\hline \multicolumn{6}{|c|}{ Carex pilosa } \\
\hline I. Querceto-Pinetum caricosum (pilosae) & $6 \mathrm{P} 4 \mathrm{Q}$ & 0.6 & 48 & 20 & 65 \\
\hline $\begin{array}{l}\text { II. Quercetum coryloso-caricosum } \\
\text { (pilosae) }\end{array}$ & 8Q2P & 0.7 & 53 & 21 & 60 \\
\hline $\begin{array}{l}\text { III. Betuleto-Quercetum coryloso- } \\
\text { caricosum (pilosae) }\end{array}$ & 6Q4B & 0.8 & 55 & 23 & 50 \\
\hline
\end{tabular}

ISSN 1996-4536 (print) •ISSN 2311-0783 (on-line) • Біологічні Студії / Studia Biologica • 2016 • Том 10/№1 • C. 187-196 
The end of the Table 1

\begin{tabular}{|c|c|c|c|c|c|}
\hline \multicolumn{6}{|c|}{ Calluna vulgaris } \\
\hline $\begin{array}{l}\text { I. Betuleto-Pinetum callunoso- } \\
\text { myrtillosum }\end{array}$ & 8P2B & 0.5 & 0.5 & 20 & 30 \\
\hline II. Pinetum callunoso-hylocomiosum & $10 P+B$ & 0.5 & 0.5 & 21 & 25 \\
\hline $\begin{array}{l}\text { III. Querceto-Pinetum } \\
\text { callunoso-hylocomiosum }\end{array}$ & 9P1Q & 0.4 & 0.4 & 18 & 35 \\
\hline \multicolumn{6}{|c|}{ Molinia caerulea } \\
\hline I. Pinetum myrtilloso-moliniosum & $6 P 1 Q+B$ & 0.6 & 52 & 23 & 55 \\
\hline $\begin{array}{l}\text { II. Querceto-Pinetum franguloso- } \\
\text { molinioso-hylocomiosum }\end{array}$ & $7 P 3 Q+B$ & 0.7 & 54 & 24 & 50 \\
\hline III. Betuleto-Pinetum moliniosum & $8 \mathrm{P} 2 \mathrm{Q}$ & 0.4 & 49 & 20 & 65 \\
\hline \multicolumn{6}{|c|}{ Stellaria holostea } \\
\hline $\begin{array}{l}\text { I. Querceto-Pinetum coryloso- } \\
\text { stellariosum }\end{array}$ & $7 P 3 Q+B$ & 0.6 & 52 & 22 & 55 \\
\hline $\begin{array}{l}\text { II. Quercetum coryloso-caricoso } \\
\text { (pilosae)-stellariosum }\end{array}$ & 8Q2P & 0.7 & 55 & 24 & 50 \\
\hline III. Querceto-Pinetum stellariosum & $6 \mathrm{P} 4 \mathrm{Q}$ & 0.5 & 51 & 21 & 60 \\
\hline \multicolumn{6}{|c|}{ Vaccinium myrtillus } \\
\hline I. Pinetum myrtilloso-hylocomiosum & $10 P+Q$ & 0.6 & 0.6 & 25 & 40 \\
\hline II. Pinetum molinioso-myrtillosum & $10 \mathrm{P}$ & 0.4 & 0.4 & 23 & 60 \\
\hline III. Querceto-Pinetum myrtillosum & $7 P 3 Q$ & 0.7 & 0.7 & 18 & 50 \\
\hline IV. Betuletum molinio-myrtillosum & $8 \mathrm{~B} 2 \mathrm{P}$ & 0.5 & 0.5 & 20 & 55 \\
\hline $\begin{array}{l}\text { V. Betuleto-Pinetum franguloso- } \\
\text { myrtillosum }\end{array}$ & $7 P 3 B+Q$ & 0.8 & 0.8 & 21 & 45 \\
\hline \multicolumn{6}{|c|}{ Vaccinium vitis-idaea } \\
\hline I. Pinetum vaccinioso-myrtillosum & $10 C+5$ & 0.4 & 0.4 & 22 & 40 \\
\hline $\begin{array}{l}\text { II. Betuleto-Pinetum vaccinioso- } \\
\text { myrtillosum }\end{array}$ & $6 \mathrm{C} 4 \mathrm{~B}$ & 0.6 & 0.6 & 24 & 45 \\
\hline $\begin{array}{l}\text { III. Querceto-Pinetum vaccinioso- } \\
\text { myrtillosum }\end{array}$ & 8С2Д+Б & 0.7 & 0.7 & 25 & 50 \\
\hline IV. Pinetum vaccinioso-hylocomiosum & 9С1Д & 0.6 & 0.6 & 21 & 40 \\
\hline
\end{tabular}

Comments: $\mathrm{P}$ - Pinus sylvestris, B - Betula pendula, Q - Quercus robur

Примітки: P - Pinus sylvestris, B - Betula pendula, Q - Quercus robur

\section{RESULTS AND DISCUSSION}

Reproduction in a broad sense is the process by which female parents generate some or other germs (diasporas) able to form new individuals that are genetically similar to female parents. Three main types of reproduction were found in forest plants: sexual, asexual and vegetative. Metasperms and gymnosperms are characterized by sexual and vegetative reproduction. One type of reproduction is often dominated. Vegetative reproduction often prevails in forest grasses. R. Ye. Levina [18] rightly emphasized that "from the point of view of the species viability strategy, vegetative reproduction and regeneration justify themselves only in combination with seed reproduction". This combination in reality is observed in plants of the lower layers of forest ecosystems.

Seed reproduction is a multiple-stage process. The first stage is the formation of generative buds, flowers and flowering, which is determined by the condition of parent plant. The second stage is a complex mechanism of pollination and fertilization, which depends not only on the condition of plants, but also as on the functions of agents provi-

ISSN 1996-4536 (print) • ISSN 2311-0783 (on-line) • Біологічні Студії / Studia Biologica • 2016 • Том 10/№1 • C. 187-196 
ding transportation of pollen. Ripening of seeds and fruits is mainly due to the vital condition of parent plants, whereas their dispersion is almost entirely dependent on external agents (excluding such phenomenon as autochory). A few monographs deal with these important issues: problems of flowering and pollination (monograph K. Fegri K. and L. van der Pale [10], problems of seed dispersion (monograph. R. Ye. Levina [17]). Methods of plant reproduction study [1] are also well developed.

The study of reproductive biology and ecology requires the explicit identification of a set of signs characterizing this process on all its stages, and must be recorded in the study of reproduction. Speaking from the perspective of forest ecology, quantitative traits of reproduction are of particular importance: number of flowers produced by the plant, magnitude of reproductive effort, number of diasporas both per individual and per unit of surface area and the like.

In case of seed reproduction, the key and critical stages are as follows: flowering and its duration, pollination, fruit and seed ripening, dispersion, preservation of seeds in the soil and the ability to form soil seed banks.

Two main types of reproduction are found in forest grasses and subshrubs: seed (or by spores in spore-bearing plants) and vegetative. Three special reviews [6, 15, 31] focus on the features of life cycle and reproduction of this group of plants.

Forest grasses and subshrubs due to the high species diversity are characterized by a wide variety of methods of pollination and seed dispersal [24]. However, in a way, the nature of reproduction of plants of the lower forest layer is a contrast to reproduction of forest forming woody species. Various forms of zoophily, especially entomophily, are predominant in the pollination of grasses and subshrubs of forest ecosystems, and zoochory is dominant among the mechanisms of fruit and seed dissemination - fruits are mostly juicy, seeds may have appendages used as food by insects. In general, animals play a leading role in pollination and distribution of diasporas of plants of the lower forest layer. This has a positive effect on the sustainable conservation of such species in the ecosystem that depends on the variety and sufficient number of species of forest fauna.

Lack of niche specialization in the pollination process is a distinctive specific feature of forest grasses in the temperate zone. Flowers are usually white or bright colored, mostly actinomorphic, so insects with different body shape and size can get nectar and spread pollen. About $40 \%$ of the species of forest grasses of forest ecosystems of the temperate zones have autogamy [4]. But, basically, the researchers record pollination deficit in forest grasses as one of the key reasons for the low level of fruiting.

When studying a large group of individuals of Actaea spicata in 25 different locations, J. P. Dahlgren et al [9] found that in $83 \%$ of cases, flowering of these plants is determined by soil temperature and stand and herbaceous layer density. Accordingly, the earliest flowering plants were found on south-facing slopes.

The range of pollinators in entomophilous species is very wide: bees, bumblebees, butterflies, beetles and other groups of insects. There are various defensors to prevent self-pollination. In Oxalis acetosella, flowers are cleistogamous, they have shortened internodes compared to normal flowers. The signs of nectar in the form of pink veins are well expressed on the petals of this plant.

Having a sufficiently broad set of defensors that provide flower pollination, forest grasses are often characterized by a low level of fruit inception which depends on the lack of pollination [11]. According to the data collected by T. Asman and others [3] for over 20 years, pollen deficit is a characteristic feature of the reproductive process of forest grasses and subshrubs.

ISSN 1996-4536 (print) • ISSN 2311-0783 (on-line) • Біологічні Студії / Studia Biologica • 2016 • Том 10/№1 • С. 187-196 
In general, all types of grasses and subshrubs are characterized by some partial divergence in flowering peaks. This is an important adaptive trait that allows plants to improve the chances of fairly complete pollination of flowers. A negative factor for pollination of nemoral and boreal species of forest grasses is forest fragmentation. In these conditions, the composition of entomofauna is dramatically changing, and insufficient flower pollination of plants of grass and subshrub layer in the fragmented forests is becoming wide-scale [30]. The size of seeds and fruits in forest grasses and subshrubs is very diverse. It ranges from big to the so-called dust-like seeds (representatives of the Orchid family). And the supply of nutrients in seeds varies accordingly [28].

The level of the production process in plants of the lower layer is largely dependent on the vitality of individuals. It in turn is determined by many factors. The structure of phytogeneous fields of forest forming species plays a significant role among them. T. V. Paal [21] has found out that in Vaccinium vitis-idaea the number of established fruits within phytogeneous fields of spruce is significantly lower than outside such fields. The activity of phytophages is even more important. Animals destroy up to $80 \%$ of fruits [24] in Actaea spicata.

Resulting effect of the renewal process of a number of plant species of grass and subshrub layer depends on the establishment of soil bank of diasporas, its species composition, duration of preservation of viability and the overall size of bank by diasporas. In broad-leaved forests, the composition of soil seed bank is dominated by diasporas of not indigenous forest species but species of open habitats [22]. In a series of papers of V. V. Petrov [25, 26, 27] it is shown that the soil supply of diasporas in coniferous indigenous forests is not large and usually comprises $1000-1500$ pieces $/ \mathrm{m}^{2}$. Among forest species, the composition of soil seed bank often includes the seeds of birch and some species of forest grasses and subshrubs (Carex pilosa and Rubus idaeus). Depending on forest type, seeds may be concentrated in some cases in litter, while in others - mainly in the mineral soil layer.

In the study of seed reproduction of forest grasses in the mixed coniferous-broad leaved forest of Bryansk region, N. Y. Bohdanova [7] found out that in some cases their seeds can be spread to a distance of $1 \mathrm{~km}$, but more often cover smaller distances. The studied plant species were characterized by autochory (shoots lodging, balistochory, amphicarpy), synzoochory (myrmecochory, seed dispersal by mouse-like rodents, birds), endozoochory. All studied species were characterized by the combination of different methods of seed dispersal.

In case of generative reproduction, an important biological characteristic is the socalled reproductive effort, which characterizes the contribution of organic matters and energy to the reproductive process. Methods of its calculation are different and depend on the life forms of plants. In most cases, reproductive effort is the proportion of phytomass of reproductive structures of the total phytomass of plant and expressed in percentage [32].

An important common feature of reproduction of the vast majority of forest grasses is the ability for vegetative reproduction and clone formation.

It is established that the main indicators of generative reproduction of clone forming plants of grass and subshrub layer depend on plant species, and are influenced by the ecological and coenotic factors (Table 2).

Three coenopopulations of $A$. podagraria, limited to such phytocoenoses as I. Quercetum coryloso-aegopodiosum, II. Querceto-Pinetum coryloso-aegopodiosum, III. 
Table 2. Average parameters of generative plant propagation

\section{Таблиця 2. Середні показники генеративного розмноження рослин}

\begin{tabular}{|l|l|l|}
\hline \multicolumn{1}{|c|}{\begin{tabular}{c} 
Number and name of association \\
\multicolumn{1}{|c|}{ Aegopodium podagraria } \\
\hline I. Quercetum coryloso-aegopodiosum
\end{tabular}} & WG, g & RE, \% \\
\hline II. Querceto-Pinetum coryloso-aegopodiosum & $0.71 \pm 0.07$ & $15.8 \pm 2.49$ \\
\hline III. Betuleto-Pinetum coryloso-aegopodiosum & $1.50 \pm 0.12$ & $13.4 \pm 0.73$ \\
\hline
\end{tabular}

Asarum europaeum
I. Quercetum coryloso-asarosum
$0.47 \pm 0.02$
$17.7 \pm 1.23$
II. Pinetum coryloso-asarosum
$0.41 \pm 0.02$
$18.1 \pm 0.53$
III. Querceto-Pinetum asarosum
$0.34 \pm 0.01$
$25.6 \pm 3.48$

\begin{tabular}{|c|c|c|}
\hline \multicolumn{3}{|c|}{ Carex pilosa } \\
\hline I. Querceto-Pinetum caricosum (pilosae) & $0.13 \pm 0.005$ & $9.8 \pm 1.55$ \\
\hline II. Quercetum coryloso-caricosum (pilosae) & $0.12 \pm 0.006$ & $7.5 \pm 0.75$ \\
\hline III. Betuleto-Quercetum coryloso-caricosum (pilosae) & $0.15 \pm 0.09$ & $7.8 \pm 0.37$ \\
\hline \multicolumn{3}{|c|}{ Calluna vulgaris } \\
\hline I. Betuleto-Pinetum callunoso-myrtillosum & $0.07 \pm 0.001$ & $2.5 \pm 0.61$ \\
\hline II. Pinetum callunoso-hylocomiosum & $0.05 \pm 0.001$ & $2.8 \pm 0.63$ \\
\hline III. Querceto-Pinetum callunoso-hylocomiosum & $0.08 \pm 0.002$ & $1.8 \pm 0.45$ \\
\hline
\end{tabular}

Molinia caerulea
I. Pinetum myrtilloso-moliniosum
$1.31 \pm 0.07$
$41.7 \pm 4.8$
II. Querceto-Pinetum franguloso-molinioso-hylocomiosum
$1.22 \pm 0.04$
$45.5 \pm 8.28$
III. Betuleto-Pinetum moliniosum
$1.25 \pm 0.05$
$34.0 \pm 4.26$

\section{Stellaria holostea}
I. Querceto-Pinetum coryloso-stellariosum
$0.26 \pm 0.03$
$22.9 \pm 1.78$
II. Quercetum coryloso-caricoso (pilosae)-stellariosum
$0.34 \pm 0.93$
$32.7 \pm 2.93$
III. Querceto-Pinetum stellariosum
$0.27 \pm 0.04$
$25.5 \pm 0.04$

\section{Vaccinium myrtillus}
I. Pinetum myrtilloso-hylocomiosum
$3.28 \pm 0.92$
$48.6 \pm 1.41$
II. Pinetum molinioso-myrtillosum
$82.6 \pm 13.16$
$54.4 \pm 0.93$
III. Querceto-Pinetum myrtillosum
$3.31 \pm 0.92$
$27.0 \pm 1.61$
IV. Betuletum molinio-myrtillosum
$60.1 \pm 11.20$
$6,8 \pm 0.94$
V. Betuleto-Pinetum franguloso-myrtillosum
$37.3 \pm 2.20$
$11.3 \pm 1.22$

Vaccinium vitis-idaea
I. Pinetum vaccinioso-myrtillosum
$17.7 \pm 1.62$
$24.4 \pm 1.56$
II. Betuleto-Pinetum vaccinioso-myrtillosum
$7.3 \pm 0.61$
$20,2 \pm 1.30$
III. Querceto-Pinetum vaccinioso-myrtillosum
$28.5 \pm 8.71$
$13.6 \pm 0.61$
IV. Pinetum vaccinioso-hylocomiosum
$0.2 \pm 0.03$
$21.7 \pm 0.12$

ISSN 1996-4536 (print) • ISSN 2311-0783 (on-line) • Біологічні Студії / Studia Biologica • 2016 • Том 10/№1 • С. 187-196 
Betuleto-Pinetum coryloso-aegopodiosum, have been studied. The weight of generative plant organs ranges from 0.7 to $1.5 \mathrm{~g}$ and is the greatest in Querceto-Pinetum coryloso-aegopodiosum association. The value of RE comprises $10.9-15.8 \%$ and is the highest in Quercetum coryloso-aegopodiosum association. This is confirmed by the data of M. G. Bashtovy [5] according to which magnitude of reproductive effort is an expression of tactics of plant protection against stress factors.

The study of coenopopulations of $A$. europaeum was carried out in three associations (I. Quercetum coryloso-asarosum, II. Pinetum coryloso-asarosum, III. QuercetoPinetum asarosum). The proportion of generative individuals in $A$. europaeum populations comprised $21.3-58.7 \%$ and was the highest in association of Querceto-Pinetum asarosum. The weight of generative structures was $0.3-0.4 \mathrm{~g}$ at RE being from 17.7 to $25.6 \%$. The highest value of RE was also in Querceto-Pinetum asarosum association.

Three populations of C. pilosa in different associations (I. Querceto-Pinetum caricosum (pilosae), II. Quercetum coryloso-caricosum (pilosae), III. Betuleto-Quercetum coryloso-caricosum (pilosae)) were examined. The feature of reproduction of $C$. pilosa is low weight of the generative organs: 0.12 to $0.15 \mathrm{~g}$. The proportion of generative bushes in populations was 38.8-to $62.4 \%$. RE amounted to 9.8-7.53 \% and was the largest in Querceto-Pinetum caricosum (pilosae) association.

Three populations of $C$. vulgaris limited to associations of I. Betuleto-Pinetum callunoso-myrtillosum, II. Pinetum callunoso-hylocomiosum, III. Querceto-Pinetum callunoso-hylocomiosum were investigated. The proportion of generative partial bushes of C. vulgaris in forest associations was 15.1-67.4 \%. In Betuleto-Pinetum callunoso-myrtillosum association this proportion was the smallest, the smallest number of flowers and fruits per generative shoot was formed in it. The maximum value of generativity was found in Querceto-Pinetum callunoso-hylocomiosum association.

$M$. caerulea is represented by three populations, limited to the following associations: I. Pinetum myrtilloso-moliniosum, II. Querceto-Pinetum franguloso-molinioso-hylocomiosum, III. Betuleto-Pinetum moliniosum. The percentage of generative individuals in forest ecosystems amounted to $11-20 \%$ and was the greatest in Betuleto-Pinetum moliniosum association. The total weight of generative structures was in the amplitude of $1.2-1.4 \mathrm{~g}$, and RE amounted to $34.0-41.7 \%$. The minimum value of RE was in Betuleto-Pinetum moliniosum association.

The study of coenopopulations of $S$. holostea limited to the various associations (I. Querceto-Pinetum coryloso-stellariosum, II. Quercetum coryloso-caricoso (pilosae)stellariosum, III. Querceto-Pinetum stellariosum) was carried out. The percentage of generative partial bushes of S. holostea in the forests amounted to 19-33\% and was the highest in Querceto-Pinetum stellariosum association, however, other reproductive morphometric parameters were the highest in Quercetum coryloso-caricoso (pilosae)stellariosum association.

The proportion of generative partial bushes in five populations of $V$. myrtillus growing in different associations (I. Pinetum myrtilloso-hylocomiosum, II. Pinetum molinioso-myrtillosum, III. Querceto-Pinetum myrtillosum, IV. Betuletum molinioso-myrtillosum, V. Betuleto-Pinetum franguloso-myrtillosum) amounted to $46-88 \%$ and was the highest in associations of Pinetum molinioso-myrtillosum and Betuletum molinioso-myrtillosum. The greatest number and weight of fruits occurred in Pinetum molinioso-myrtillosum association. Their average yield was $3.3-92.6 \mathrm{~g} / \mathrm{m}^{2}$, meaning that it varied very much by associations and years. RE was in the amplitude of 5.4 to $54.4 \%$.

ISSN 1996-4536 (print) • ISSN 2311-0783 (on-line) • Біологічні Студії / Studia Biologica • 2016 • Том 10/№1 • С. 187-196 
The study of four populations of $V$. vitis-idaea from different associations (I. Pinetum vaccinioso-myrtillosum, II. Betuleto-Pinetum vaccinioso-myrtillosum, III. QuercetoPinetum vaccinioso-myrtillosum, IV. Pinetum vaccinioso-hylocomiosum) was carried out. The proportion of generative partial bushes of $\mathrm{V}$. vitis-idaea amounted to $8.7-34.5 \%$ and was the highest in associations of Betuleto-Pinetum vaccinioso-myrtillosum and Querceto-Pinetum vaccinioso-myrtillosum. Querceto-Pinetum vaccinioso-myrtillosum association is differed by the highest yield per unit of area. This figure ranged from 0.2 to $28.5 \mathrm{~g} / \mathrm{m}^{2}$ in associations. Positive correlation of yield with the size of partial bush ( $\mathrm{v}=$ $+0,64$ ) was observed. RE was $13.6-24.4 \%$.

Conclusions. The study of 8 model plant species of grass and subshrub layer in forest ecosystems of the north-eastern part of Ukraine, represented by 27 populations was conducted. It was found out that the smallest contribution to the reproduction organs is characteristic for $C$. vulgaris amounting to $2 \%$, and the highest one for coenopopulations of $M$. caerulea (almost $50 \%$ ). Overall, generativity of the studied plants of grass and subshrub layer is determined by the ecological and coenotic factors, and therefore is consistently varied from association to association.

1. Andreeva E.N., Bakal I.Yu., Gorshkov V.V., Lianguzova I.V. Study methods of forest communities. St. Petersburg: Chemistry Research Institute of the State University, 2002. 240 p. (In Russian).

2. Andriyenko T.L. Phytodiversity of Ukrainian Polissya and its protection. Kyiv: Phytosociocentre, 2006. 316 p. (In Ukrainian).

3. Ashman T.L., Knight T.M., Steets J.A. et al. Pollen limitation of plant reproduction: ecological and evolutionary causes and consequences. Ecology, 2004; 85(9): 2408-2421.

4. Barrett S. C., Helenurm K. The reproductive biology of boreal forest herbs. I. Breeding system and pollination. Canad. J. Bot, 1987; 65: 2036-2046.

5. Bashtovoi N.G. Strategy of gout weed and Solomon's seal protection in cenopopulations under the conditions of anthropogenic loads. In: Plant populations: principles of organization and problems of nature protection. Yoshkar-Ola, 1991. P. 67. (In Russian).

6. Bierzychudek $P$. Life histories and demography of sade-tolerant temperate forest herbs: a review. New Phytol, 1982; 90: 757-776.

7. Bogdanova N.E. Features of seed dispersal of model grass species in a coniferous-deciduous forest. In: Actual problems of geobotany. Part 1. Petrozavodsk, 2007: 67-70. (In Russian).

8. Bulokhov A.D., Solomeshch A.I. Ecological and floristic classification of the forests of southern Nechernozemie of Russia. Bryansk: BGU, 2003. 359 p. (In Russian).

9. Dahlgren J.P., Zeipel H., Ehrlen J. Variation in vegetative and flowering phenology in a forest herb caused by environmental heterogeneity. Amer. J. Botan, 2007; 94(9): 1570-1576.

10. Fegri K., Van der Pale L. Fundamentals of ecology of pollination. Moscow: Mir, 1962. 379 p. (In Russian).

11. Ghazoul J. Pollen and seed dispersal among dispersed plants. Biol. Rev, 2005; 80: 413-443.

12. Honcharenko I.V. Vegetation analysis of the north-eastern forest-steppe of Ukraine. Kyiv: Phytosociocentre, 2003. 203 p. (In Ukrainian).

13. Hryhora I.M., Solomakha V.A. Vegetation of Ukraine (ecological-coenotic, floristic and geographical study). Kyiv: Phytosociocentre, 2005. 452 p. (In Ukrainian).

14. Kovalenko I.M. Ecology of the lower layer plants of forest ecosystems: monograph. Sumy: University Book, 2015. 360 p. (In Ukrainian).

15. Kovalenko I.M. Generative reproduction of clone forming plants of grass and subshrub layer under forest phytocenosis of National Nature Park "Desniansko-Starogutsky". In: Actual problems of botany and ecology. Kyiv: Phytosociocentre, 2005. P. 130-132. (In Ukrainian).

16. Kurnaev S.F. The main forest types of the middle Russian plain. Moscow: Nauka, 1968. 355 p. (In Russian).

ISSN 1996-4536 (print) • ISSN 2311-0783 (on-line) • Біологічні Студії / Studia Biologica • 2016 • Том 10/№1 • С. 187-196 
17. Levina R.E. The ways of fruit and seed dispersal. Moscow: Nauka, 1957. 358 p. (In Russian).

18. Levina R.E. Reproductive biology of seed plants. Moscow: Nauka, 1981. 96 p. (In Russian).

19. Matuszkiewicz W. Przewodnik do oznaczania zbiorowisk roślinnych Polski. Warszawa: PWN, 2001. 537 p.

20. Onyshchenko V.A. Forests of order Fagetalia sylvaticae in Ukraine. Kyiv: Alterpress, 2009. 212 p. (In Ukrainian).

21. Paal T.V., Paal Ya.L. The influence of phytogenic tree fields on the yield of bilberry. Plant Resources, 1981; 17(1): 68-74.

22. Palkina T.A., Petrov V.V. Soil stock of viable seeds in the three forest phytocenosises of different origin. Bulletin of Moscow Society of Naturalists (Biological Series), 1986; 91(2): 144-152. (In Russian).

23. Panchenko S.M. Forest vegetation of National Nature Park "Desniansko-Starogutsky". Sumy: University Book, 2013. 312 p. (In Ukrainian).

24. Persival M.S. Floral biology. Oxford: Pergamon Press, 1965. 243 p.

25. Petrov V.V. Content of dormant viable seeds in the soil of some types of coniferous forests. Vestnik MGU (Biological Series), 1981; 3: 308-312. (In Russian).

26. Petrov V.V. Some results of studying the soil supply of viable seeds of plants in the forests near Moscow. Reports of Moscow Society of Naturalists (Zoology and Botany Series), 1983; 126-128. (In Russian).

27. Petrov V.V. Content of dormant viable seeds in the soil of indigenous old-growth spruce forests. Botanical Journal, 1986; 71(9): 1227-1230.

28. Shutov V.V. Structure, dynamics and fruiting of populations of subshrub plants. Kostroma: KGTU, 2000. 100 p.

29. Solomakha V.A. Syntaxonomy of vegetation of Ukraine. Kyiv: Phytosociocentre, 2008. 296 p. (In Ukrainian).

30. Taki H., Kevan P. G., Ascher J. S. Landscape effects of forest loss in a pollination system. Landscape Ecol, 2007; 22: 1575-1587.

31. Whigham D.E. Ecology of woodland herbs in temperate deciduous forest. Ann. Rev. of Ecol., Evol. a. Syst, 2004; 35: 583-621.

32. Zlobin Yu.A. Reproductive effort. Embryology of Flowering Plants, 2000; 3: 251-258.

\section{ОСОБЛИВОСТІ РЕПРОДУКЦІЇ ТРАВ І ЧАГАРНИЧКІВ У ЛІСОВИХ ФІТОЦЕНОЗАХ}

\section{І. М. Коваленко}

Сумський національний аграрний університет вул. Г. Кондратьєва, 160, Суми 40021, Україна e-mail: kovalenko_977@mail.ru

Північний схід України, порівняно з іншими регіонами разом з Карпатами відзначається високою лісистістю. На фрормування ярусу дерев (перші етапи відновлення деревних порід) досить суттєво впливає трав'яно-чагарничковий ярус. Дослідження проведені в лісових фрітоценозах національного природного парку “Деснянсько-Старогутський” і на прилеглих територіях. Об'єктами дослідження виступали модельні види рослин трав'яно-чагарничкового ярусу (Aegopodium podagraria L., Asarum europaeum L., Calluna vulgaris (L.) Hull, Carex pilosa Scop., Molinia caerulea (L.) Moench., Stellaria holostea L., Vaccinium myrtillus L., Vaccinium vitis-idaea L.), представлені 3-5 ценопопуляціями кожний. Лісові трави і чагарнички мають дві основні форми розмноження: насінне (або спорами у спорових рослин) і вегетативне. За генеративного розмноження важливою біологічною характеристикою $є$ так зване репродуктивне зусилля, яке характеризує внесок органічних речовин і енергії в репродуктивний процес. Важлива загальна особливість репродукції переважної

ISSN 1996-4536 (print) • ISSN 2311-0783 (on-line) • Біологічні Студії / Studia Biologica • 2016 • Том 10/№1 • С. 187-196 
більшості лісових трав полягає у здатності до вегетативного розмноження і формування клонів. Встановлено, що основні показники генеративного розмноження клоноутворюючих рослин трав'яно-чагарничкового ярусу залежать від виду рослин і перебувають під впливом еколого-ценотичних фракторів. 3'ясували, що найменший внесок у органи репродукції характерний для C. vulgaris - на рівні 2 \%, а найбільший - для ценопопуляцій M. caerulea (майже 50 \%). У цілому, генеративність досліджуваних рослин трав'яно-чагарничкового ярусу визначалась еколого-ценотичними умовами, тому закономірно змінювалася від асоціації до асоціації.

Ключові слова: репродукція, лісові екосистеми, трави і чагарнички, репродуктивне зусилля.

\section{ОСОБЕННОСТИ РЕПРОДУКЦИИ ТРАВ И КУСТАРНИЧКОВ В ЛЕСНЫХ ФИТОЦЕНОЗАХ}

\section{И. Н. Коваленко}

Сумской национальный аграрный университет ул. Г. Кондратьева, 160, Сумы 40021, Украина e-mail: kovalenko_977@mail.ru

Северо-восток Украины, по сравнению с другими регионами вместе с Карпатами, отличается высокой лесистостью территории. На фрормирование древесного яруса (первые этапы восстановления леса) весьма существенно влияет травяно-кустарничковый ярус. Исследования проведены в лесных фритоценозах национального природного парка “Деснянско-Старогутский" и на прилегающих территориях. Объектами исследования являются модельные виды растений травяно-кустарничкового яруса (Aegopodium podagraria L., Asarum europaeum L., Calluna vulgaris (L.) Hull, Carex pilosa Scop., Molinia caerulea (L.) Moench., Stellaria holostea L., Vaccinium myrtillus L., Vaccinium vitis-idaea L.), представленные 3-5 ценопопуляциями каждый. Лесным травам и кустарничкам свойственны две основные формы размножения: семенное (или спорами у споровых растений) и вегетативное. При генеративном размножении важной биологической характеристикой является так называемое репродуктивное усилие, которое характеризует вклад органических веществ и энергии в репродуктивный процесс. Важная общая особенность репродукции подавляющего большинства лесных трав заключается в способности к вегетативному размножению и формированию клонов. Установлено, что основные показатели генеративного размножения клонообразующих растений травянокустарничкового яруса зависят от вида растений и находятся под влиянием эколого-ценотических факторов. Выяснили, что наименьший вклад в органы репродукции характерен для C. vulgaris - на уровне $2 \%$, а наибольший - для ценопопуляций M. caerulea (почти 50 \%). В целом, генеративность исследуемых растений травяно-кустарничкового яруса определялась эколого-ценотическими условиями, поэтому закономерно изменялась от ассоциации к ассоциации.

Ключевые слова: репродукция, лесные экосистемы, травы и кустарнички, репродуктивное усилие.

Одержано: 24.02.2016

ISSN 1996-4536 (print) • ISSN 2311-0783 (on-line) • Біологічні Студії / Studia Biologica • 2016 • Том 10/№1 • С. 187-196 